\title{
Comparison of Surface-Wind Fields between Typhoon 0418 (Songda) and Typhoon 9119 (Mireille) in Western Japan
}

\author{
by \\ Fumiaki Fujibe $^{1}$, Naoko Kitabatake ${ }^{2}$, Kotaro Bessho ${ }^{2}$ and Shunsuke Hoshino ${ }^{2}$ \\ 1. Forecast Research Department, 2. Typhoon Research Department, \\ Meteorological Research Institute, 1-1 Nagamine, Tsukuba, Ibaraki, 305-0052 Japan
}

(Received November 16, 2005; Accepted January 27, 2006; Published December 19, 2006)

\begin{abstract}
The wind fields in Typhoon 0418 (Songda; 7 to 8 September 2004) and Typhoon 9119 (Mireille; 27 to 28 September 1991), which hit western Japan on nearly the same track and caused extensive wind damage, were analyzed using routine data of the Japan Meteorological Agency. In T0418, the strongest wind was on the right (southeastern) side of the center, while the wind on the left (northwestern) side was relatively weak. This wind distribution is roughly explained by the sum of an axially symmetric vortex and the storm motion. The strong wind of T9119 was both on the right (southeastern) side and in the left-rear (western) quadrant, coinciding with a region of low temperature and a rain-band. It is likely that the dry-air intrusion into the rain-band caused evaporative cooling and generated a surge of cold air. Such a feature was lacking in T0418, for which convective clouds in the western quadrant had almost disappeared after landfall.
\end{abstract}

\section{Introduction}

The Japanese islands are often hit by tropical cyclones (TCs) in summer and autumn. In 2004, the main islands of Japan (Honshu, Kyushu, Shikoku, and Hokkaido) experienced the landfall of ten TCs, including six storms that had typhoon intensity (max. wind $\geqq 64 \mathrm{kt}$ ). Among them, T0418 (Songda) had the lowest central pressure (945hPa at landfall) and caused severe wind damage from 7 to 8 September. The track of T0418 was close to that of T9119 (Mireille), which also generated severe winds on 27 to 28 September 1991 (Fig. 1).

Most of the TCs that hit mainland Japan are distorted due to topography and/or entering a baroclinic zone, so that they sometimes exhibit complicated features such as mesoscale fronts, pressure dips, and topographically intensified winds (Yamamoto et al., 1963; Sakakibara et al., 1985; Fujibe et al., 1995; Matsumoto and Okamura, 1985; Fudeyasu and Hayashi, 2001, 2003; Saito, 1994; Nakamura et al., 2002). However, mesoscale wind fields for such TCs have been poorly documented in contrast to detailed research on the structure of mature typhoons and hurricanes.

\footnotetext{
Corresponding author: Fumiaki Fujibe,

Meteorological Research Institute, Tsukuba 305-0052, Japan.

E-mail: ffujibe@mri-jma.go.jp
}

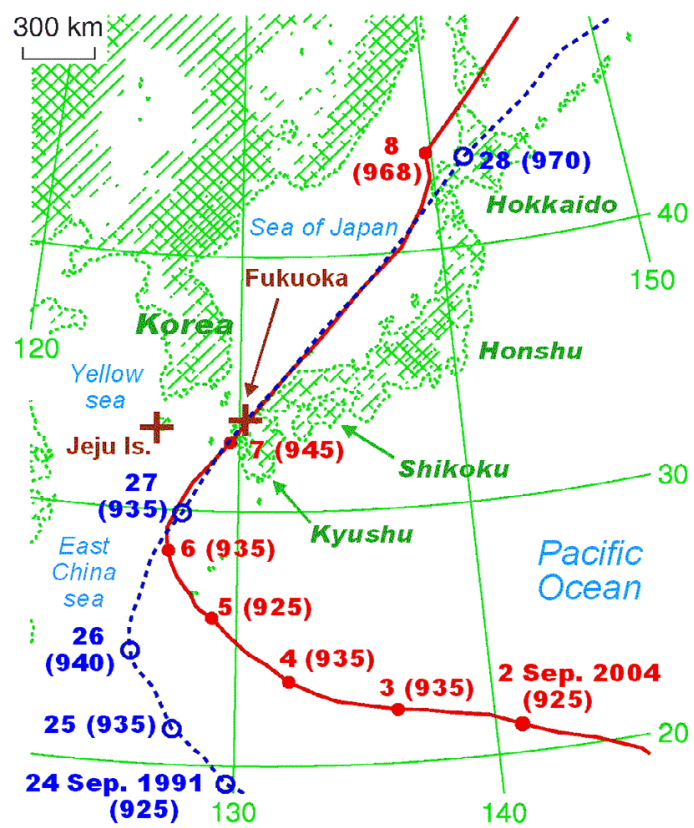

Fig. 1 Tracks of T0418 (Songda, red solid line) and T9119 (Mireille, blue dotted line). Circles indicate the position of the center at $0900 \mathrm{JST}(=0000$ UTC). Hatching indicates the area higher than $300 \mathrm{~m}, 600 \mathrm{~m}$, and $1200 \mathrm{~m}$ above m.s.l. with increasing tones (in Figs. 2, 7, 9, and also 11-14). 
To improve the alert system for winds, we need to extend our knowledge of the wind fields of TCs passing the Japanese islands.

Fujibe and Fujitani (1993) analyzed the wind fields of T9119 with attention to the asymmetric wind fields as it passed Kyushu. They discovered strong winds on the right side of the center and also in the left-rear quadrant of the center, accompanied by a mesoscale cold front and an intense rain-band. They pointed out that a similar wind distribution was found with other typhoons.

In this article, we describe the surface-wind fields of T0418 and T9119 in a search for the variability of mesoscale wind distribution in typhoons.

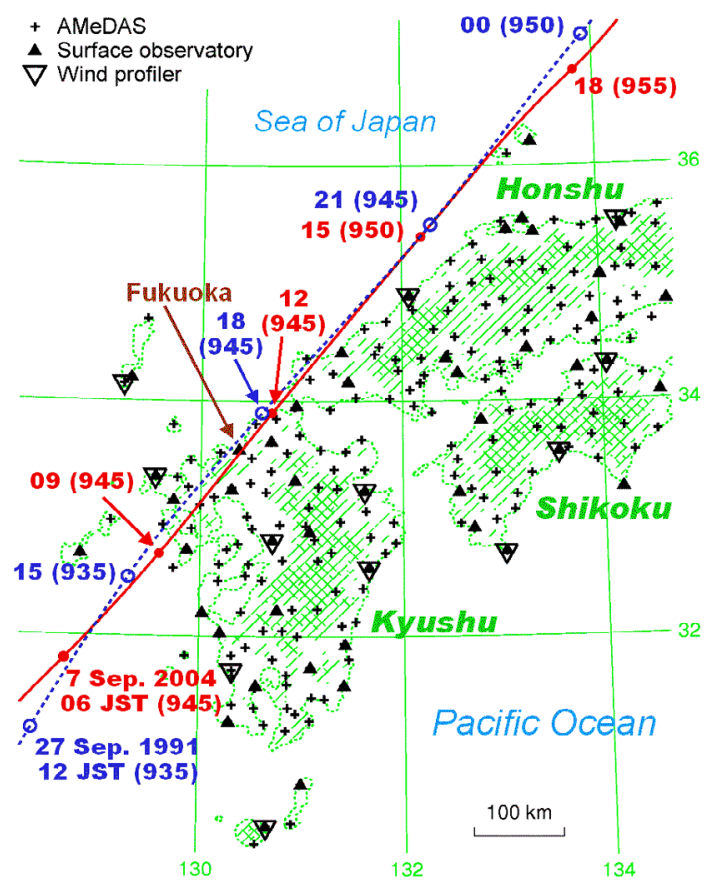

Fig. 2 Tracks of T0418 (Songda, red solid line) and T9119 (Mireille, blue dotted line) in western Japan, and the distribution of observation stations. Circles indicate three-hourly positions of the typhoon center.

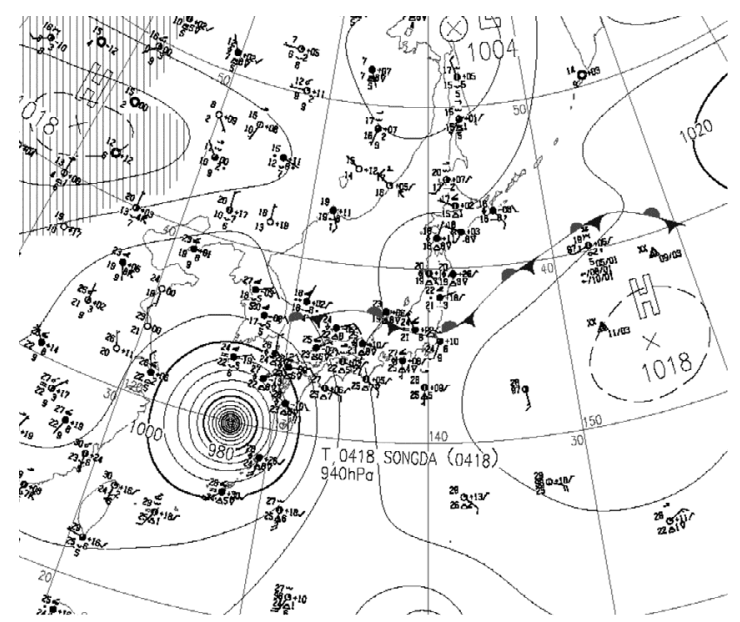

\section{Data}

The data for surface wind, temperature, and rainfall were available from the Automated Meteorological Data Acquisition System (AMeDAS) of the Japan Meteorological Agency (JMA). The time intervals are ten minutes for 2004 and an hour for 1991. Hourly and minimum sea-level pressure and peak gust are recorded at meteorological observatories of the JMA. In 2001, a wind-profiler network at about 30 sites began to provide ten-minute data of upper-level wind with a vertical resolution of approximately $300 \mathrm{~m}$. Figure 2 indicates the tracks of T0418 and T9119 in western Japan, and the locations of observation stations. Some of them have undergone changes in site and/or anemometer height, but these changes are not likely to affect the analysis described in the following.

Since surface wind speed is highly dependent on observational environments and the anemometer height, the wind-speed data were adjusted using the monthly average of daily-maximum wind speed $\left(<U_{\max }>\right)$ as

$$
U_{i}^{\prime}=\frac{<U_{\max , 0}>}{<U_{\max , i}>} U_{i}
$$

where $U_{i}$ and $U_{i}^{\prime}$ are the original and adjusted wind speed at station $i$, and $\left\langle U_{\max , 0}\right\rangle$ is the spatial mean of $<U_{\max }>$. To avoid the influence of exceptionally strong winds of the typhoon, the three largest values in the month were omitted in obtaining $<U_{\max }>$. This adjustment is based on an assumption that $<U_{\max }>$ should be spatially uniform if the anemometer height and local effects around the observation sites are uniform. This may be a very crude assumption, but $U^{\prime}$ results in a much smoother wind field than when using the original data. The reason we use the daily maximum rather than daily-mean wind speed is to avoid the influence of low wind speed under strong radiation inversion during nighttime.

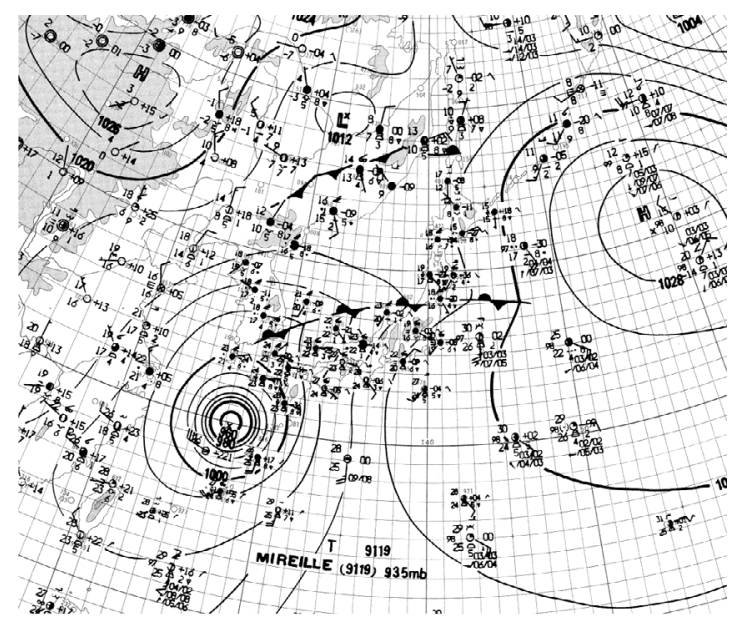

Fig. 3 Surface analysis for each typhoon (JMA). (a) 2100 JST 6 September 2004, (b) 0900 JST 27 September 1991. 
The tracks and central pressure of the typhoons were obtained from the three-hourly best-track data of the JMA. The cubic-spline functions of Akima (1970) were used to interpolate the three-hourly positions of the center as functions of time.

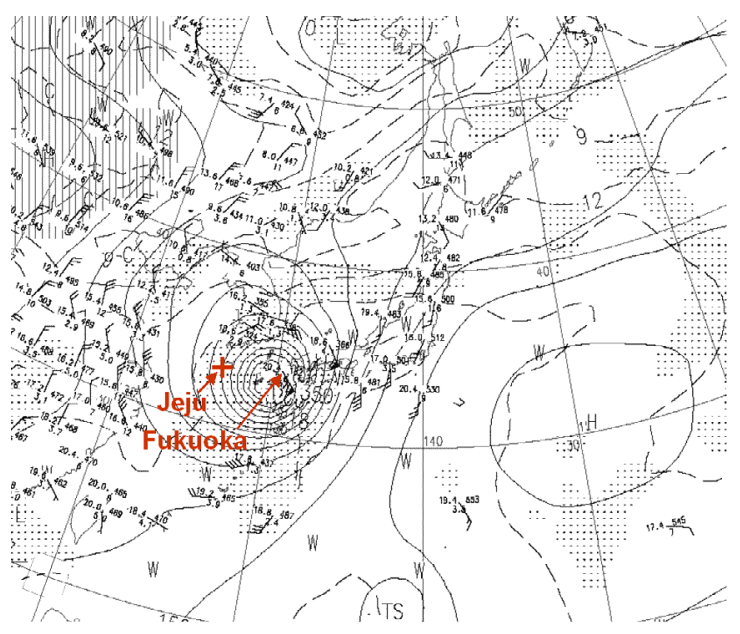

Fig. 4 The 850hPa analysis for each typhoon (JMA). (a) 0900 JST 7 September 2004, (b) 2100 JST 27 September 1991.

\section{Synoptic Situation}

Both T0418 and T9119 moved northward from the western Pacific to the East China Sea along the western side

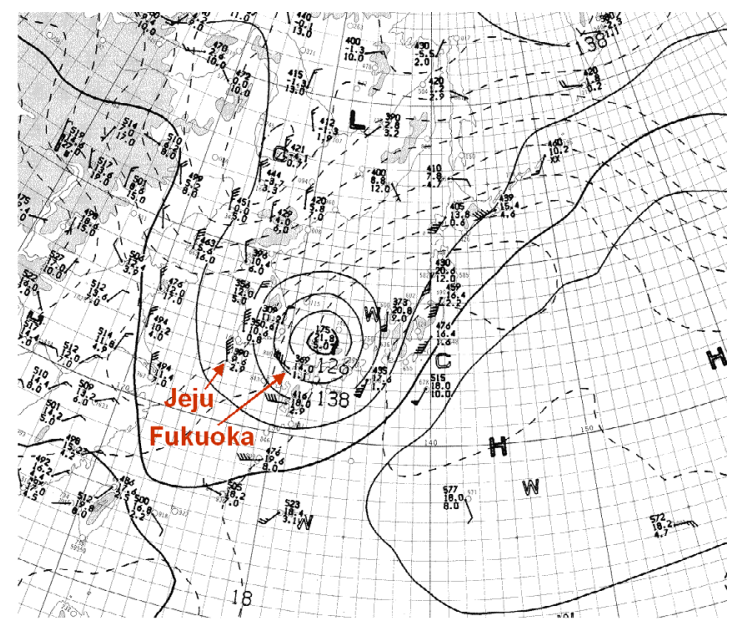

Wind direction (deg) Wind speed $(\mathrm{m} / \mathrm{s})$

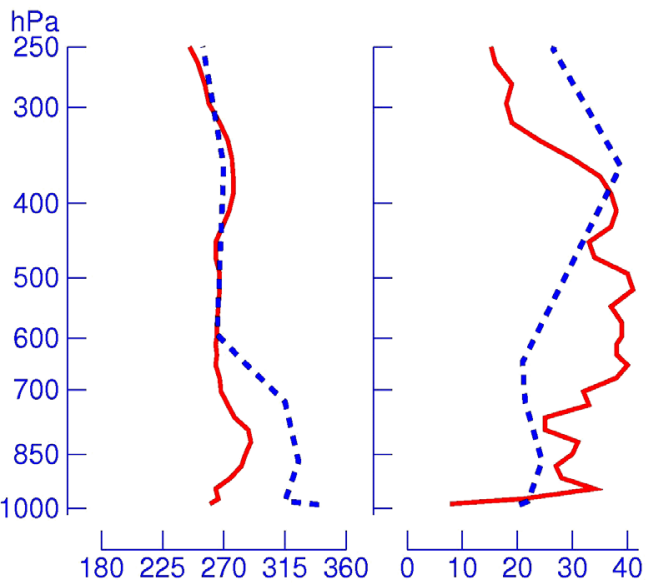

Temperature and dew point $\left({ }^{\circ} \mathrm{C}\right)$
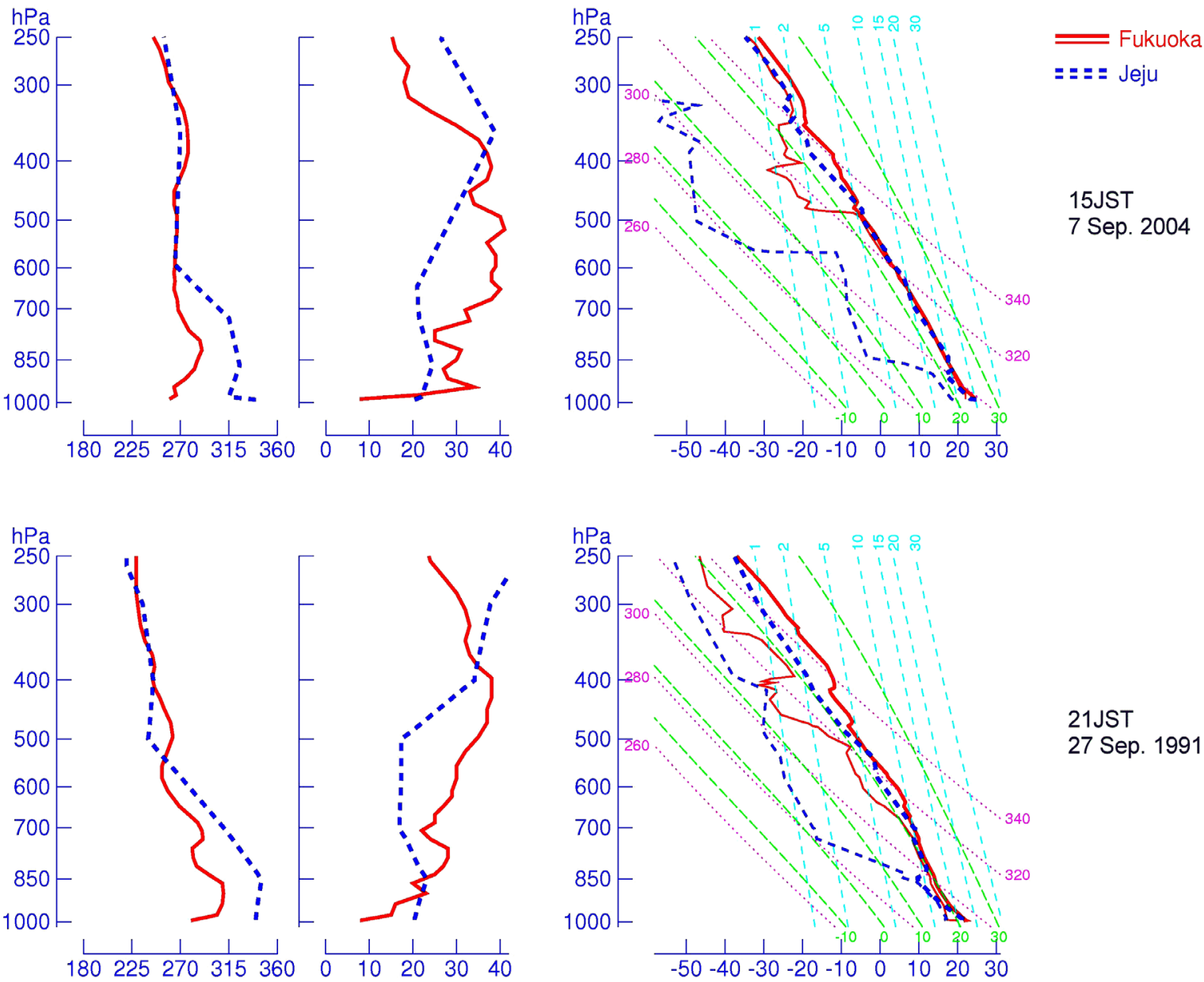

21JST

27 Sep. 1991

Fig. 5 Emagrams and wind profiles at Fukuoka and Jeju Island (see Figs. 1 and 4) at 1500 JST 7 Sep. 2004 and 2100 JST 27 Sep. 1991 
of the Pacific high. Figure 3 illustrates the surface weather maps before their landfall on Kyushu. In each case, there was a stationary front from central Honshu to the southern part of the Sea of Japan. The $850 \mathrm{hPa}$ charts (Fig. 4) indicate that the temperature difference across the frontal zones was about $10^{\circ} \mathrm{C}$. After the typhoons passed Kyushu, they began extratropical transition, which completed near Hokkaido the next day.

Figure 5 depicts the vertical soundings at Fukuoka and Jeju Island at 1500 JST 7 Sept. 2004 and 2100 JST 27 Sept. 1991, when the two typhoons were in the southern part of

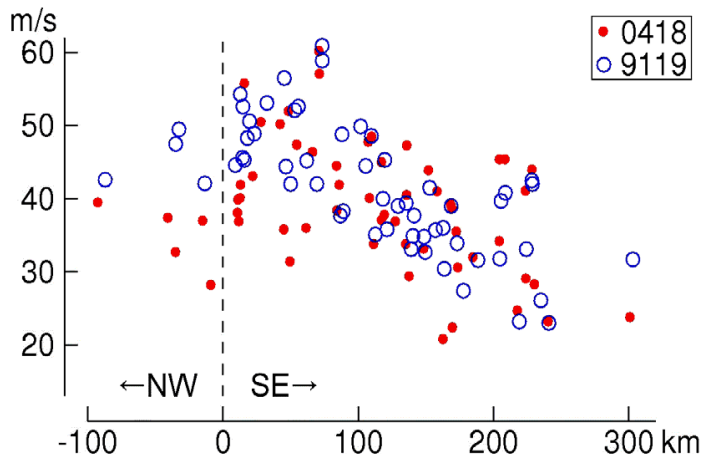

Fig. 6 Peak gusts at JMA observatories in western Japan (Kinki, Chugoku, Shikoku, and Kyushu districts, except Mie prefecture) plotted with respect to the distance from the typhoon track. the Sea of Japan (Figs. 2 and 4). In both cases, the troposphere was nearly saturated over Fukuoka, which was about $250 \mathrm{~km}$ southwest of the typhoon centers, while there was very dry air over Jeju Island located about $400 \mathrm{~km}$ west of Fukuoka. In the previous soundings (0900 JST each day; not shown), no dry regions were observed at Jeju except for levels above $500 \mathrm{hPa}$. Thus, dry air was intruding into the western portion of the storms as they moved northward into the frontal zones.

\section{Comparison of Surface-Wind Fields Between the Two Typhoons}

The two typhoons moved northeastward through the northwest part of Kyushu at a speed of 50 to $60 \mathrm{~km} / \mathrm{h}$. The central pressure at landfall was $945 \mathrm{hPa}$ for $\mathrm{T} 0418$ and $940 \mathrm{hPa}$ for $\mathrm{T} 9119$, and remained below $950 \mathrm{hPa}$ until they moved into the Sea of Japan. Figure 6 indicates the peak gust at each station plotted against the distance from each typhoon's track. There is no remarkable difference between the cases on the southeastern side of the tracks. The highest wind area is located within $100 \mathrm{~km}$ southeastward of the tracks, with peak gusts exceeding $50 \mathrm{~ms}^{-1}$ at five stations for T0418 and eight stations for T9119. Near and on the northwestern side of the track, however, the peak gusts in T9119 are substantially higher than those in T0418. Figure 7 displays the distribution of peak gusts due to each typhoon.

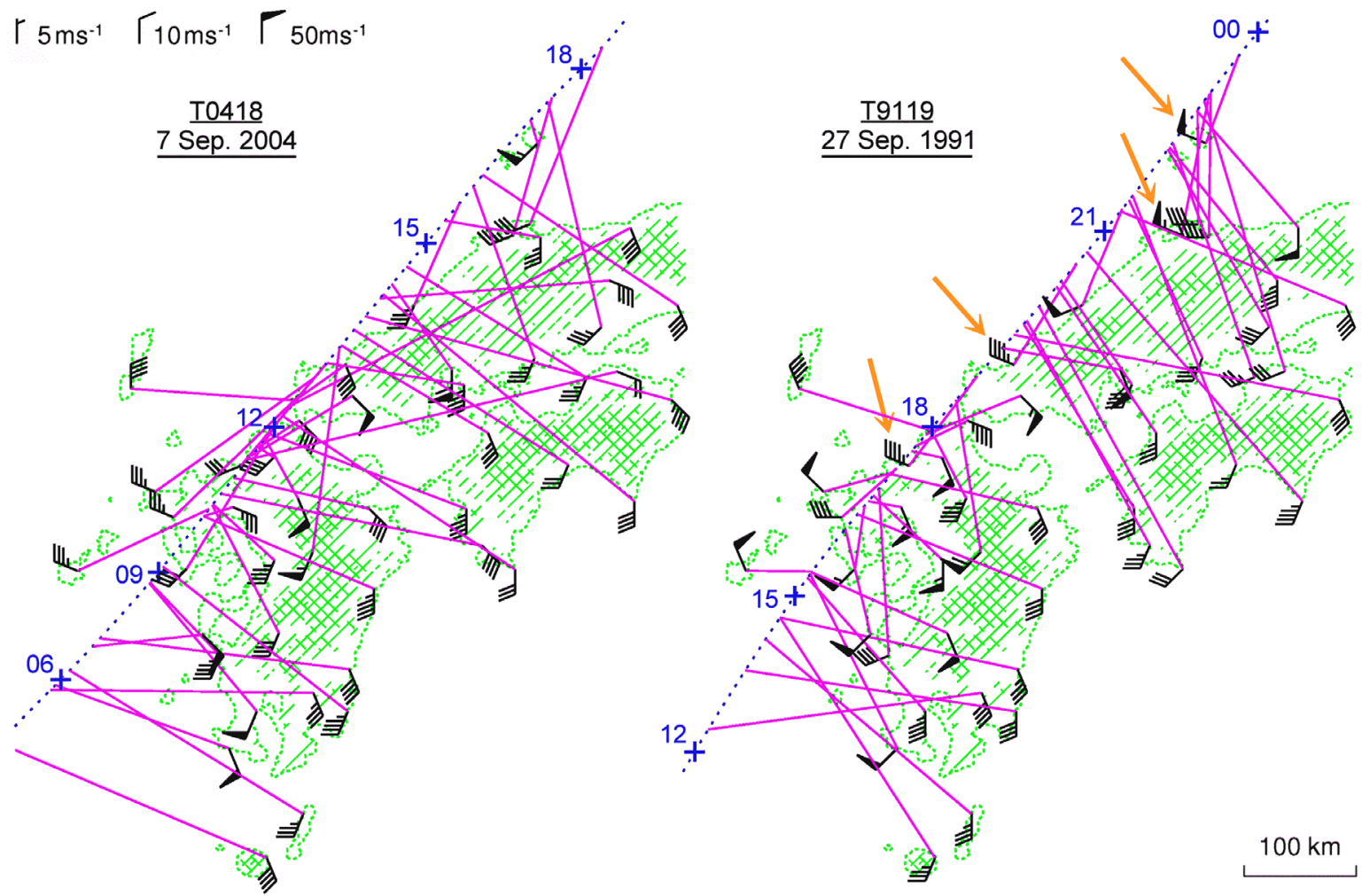

Fig. 7 Peak gusts (barbs and pennants) at JMA observatories during the passage of each typhoon. The blue dotted line indicates the storm track, with three-hourly positions indicated in crosses. The pink solid lines indicate the corresponding position of the typhoon. See text for orange arrows. 

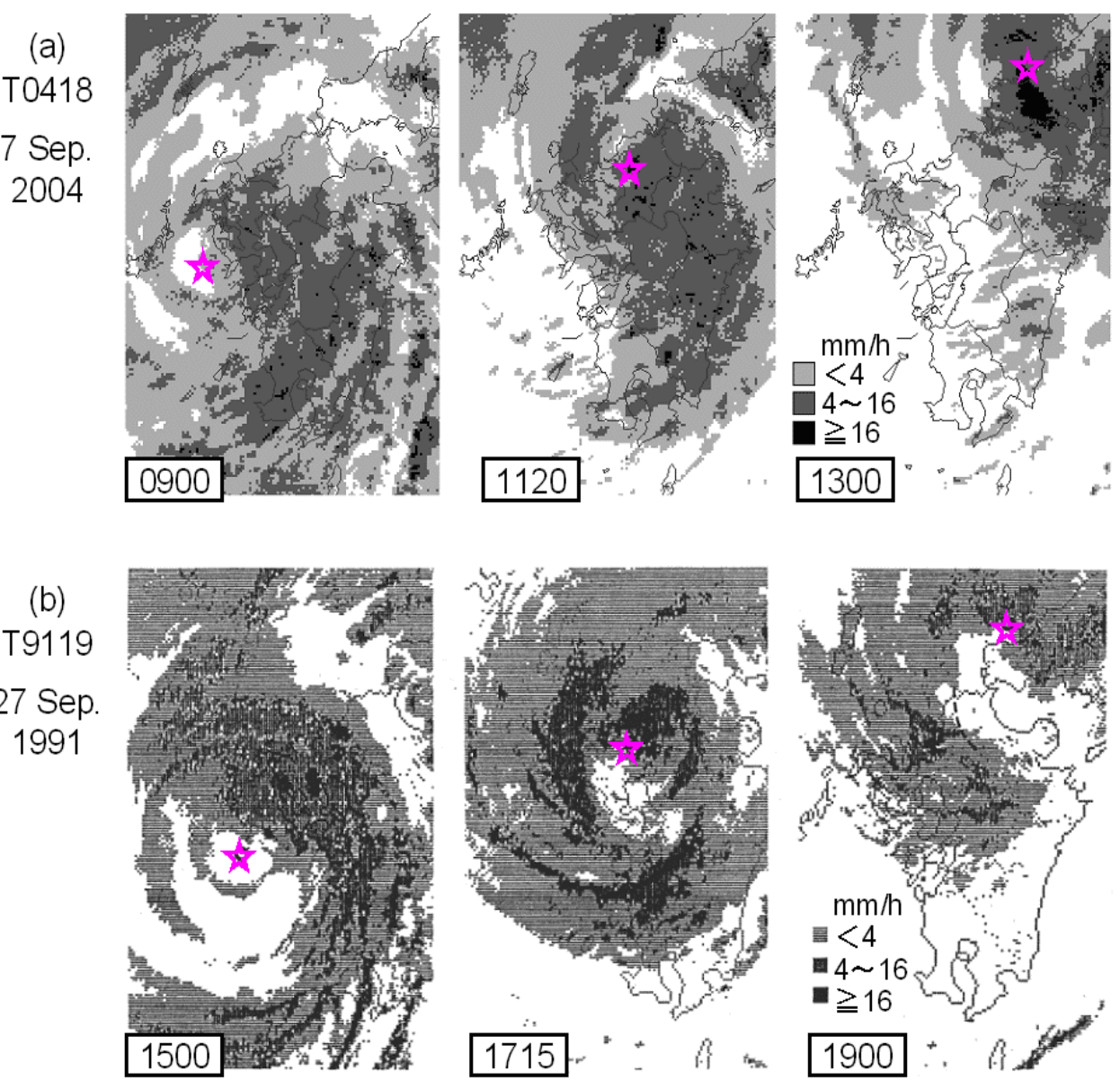

Fig. 8 Radar echoes for the two typhoons. The typhoon center is indicated with pink stars.
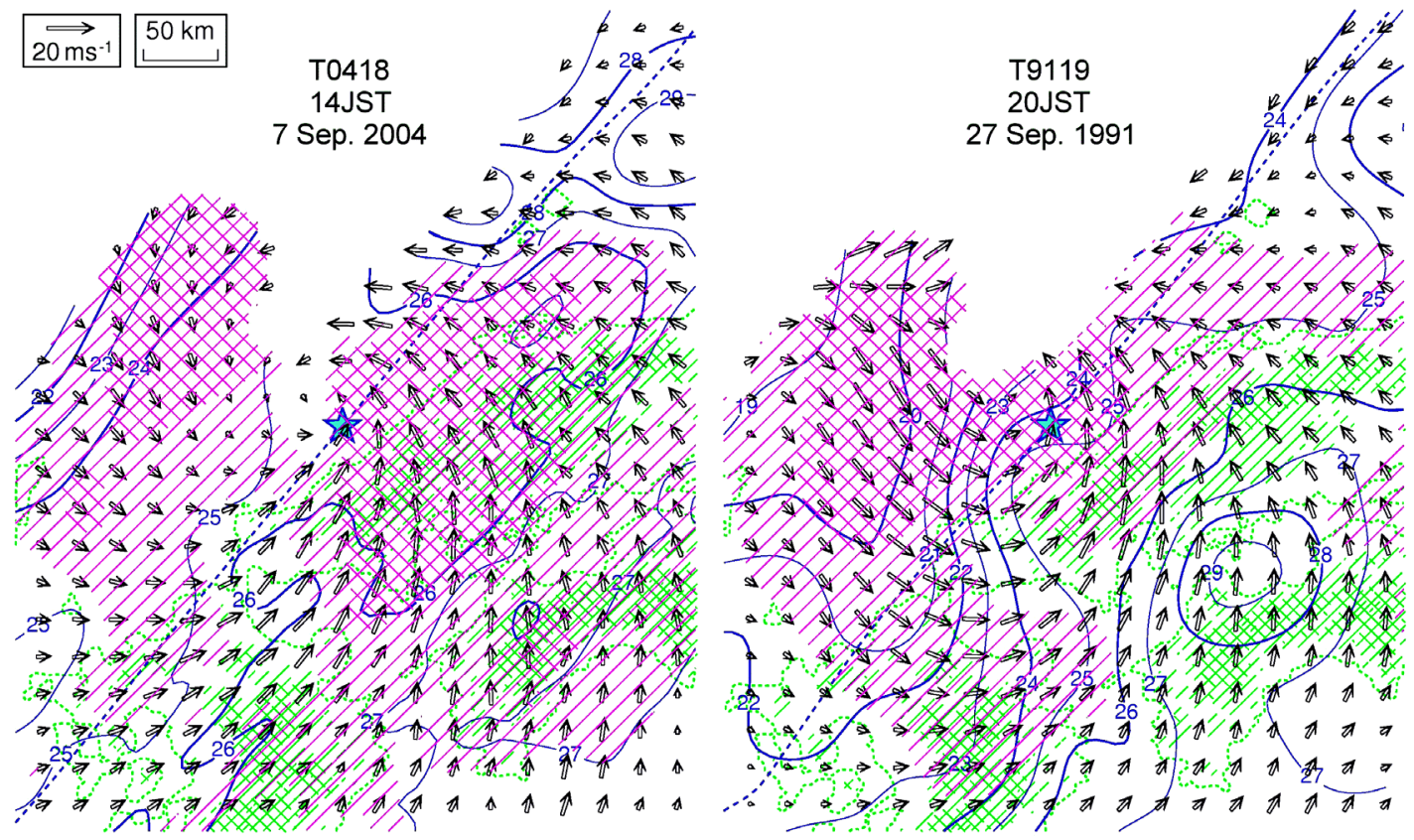

Fig. 9 Composite fields of wind vector (arrows), temperature (isotherms in blue with $1^{\circ} \mathrm{C}$ intervals), and rainfall intensity (pink hatching; $\geqq 2 \mathrm{~mm} / \mathrm{h}$ and $\geqq 8 \mathrm{~mm} / \mathrm{h}$ with increasing tones) for four hours around the time displayed (see text for details). The blue dotted lines indicate the storm track, and the stars indicate the center. 
The peak gusts along the track of T9119 were northwesterly at some stations whereas they were southwesterly in the case of T0418, as denoted by the orange arrows in Fig. 7.

Figure 8 displays the composite radar echoes of the JMA. Each typhoon had a well-defined eye surrounded by spiral rain-bands before reaching the coast of Kyushu. After landfall, the eyes became obscure and cloud bands began to lose their spiral shape. However, a NW-SE oriented rain-band remained about $200 \mathrm{~km}$ behind the center of T9119, while there were only scattered echoes behind T0418, except near the center.

To obtain the average surface fields around the typhoon center during the passage in and around Kyushu, a composite analysis was made by superimposing data at different observation times with respect to the center. For T0418, ten-minute AMeDAS data from 1140 JST to 1530 JST were superimposed after adjusting the deviation of the storm position from that at 1400 JST 7 September. For T9119, hourly data from 1800 JST to 2100 JST were superimposed after adjusting the deviation of the storm position from that at 2000 JST 27 September. During these four-hour periods, the typhoons maintained a central pressure of 945 to $950 \mathrm{hPa}$ (Fig. 2), aside from a somewhat increasing asymmetry with time (Fig. 14), so that the composite analysis makes it possible to compare their representative features of wind and temperature fields. Figure 9 presents the resulting composite fields. There is a rough similarity in the wind fields in the southern and eastern quadrants of the two typhoons. On their western side, the wind in T0418 was relatively weak, while T9119 was accompanied by strong northwesterly winds and low temperature, coinciding with an area of heavy rain due to the rain-band in Fig. 8.

Figure 10 plots the time series at Fukuoka for the two cases. In the case of T9119, there was a sudden temperature drop $\left(3.5^{\circ} \mathrm{C}\right.$ in 30 minutes $)$ followed by heavy rainfall and a strong northwest wind at about $1830 \mathrm{JST}$, which was about an hour after the passage of the center. This change corresponds to a cold-front-like feature upon arrival of the rain-band. It is to be noted that a sharp pressure drop called a "pressure dip" (Fujii et al., 1992; Maeda, 1994) accompanied the end of the rainfall. In the case of T0418, precipitation was weak after the passage of the center, and the temperature change was small except for a temporary rise of about $2^{\circ} \mathrm{C}$ around $1300 \mathrm{JST}$.

Figure 11 illustrates the sea-level pressure distribution for the two typhoons. In both cases, the pressure gradient was stronger behind the center than in front of it. This asymmetry may be explained by an orographic effect characterized by ridging on the upstream side and troughing on the downstream side (Smith, 1982). However, the pressure gradient of T9119 behind the center is almost twice that of T0418, in spite of a nearly equal pressure gradient in front of their centers. This fact indicates that the pressure gradient behind T9119 was intensified corresponding to the

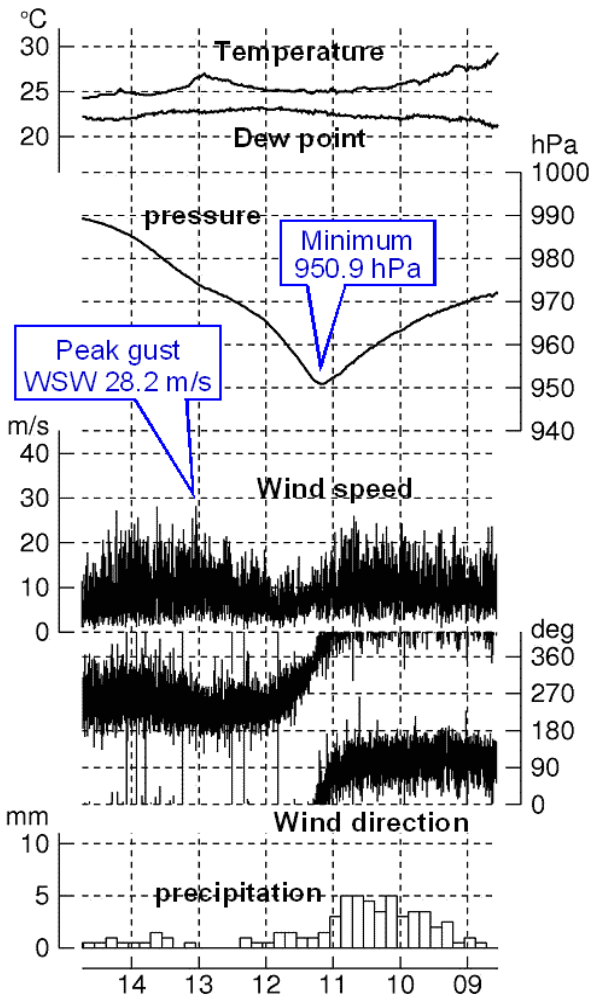

(a) T0418 (09-14 JST 7 Sep. 2004)

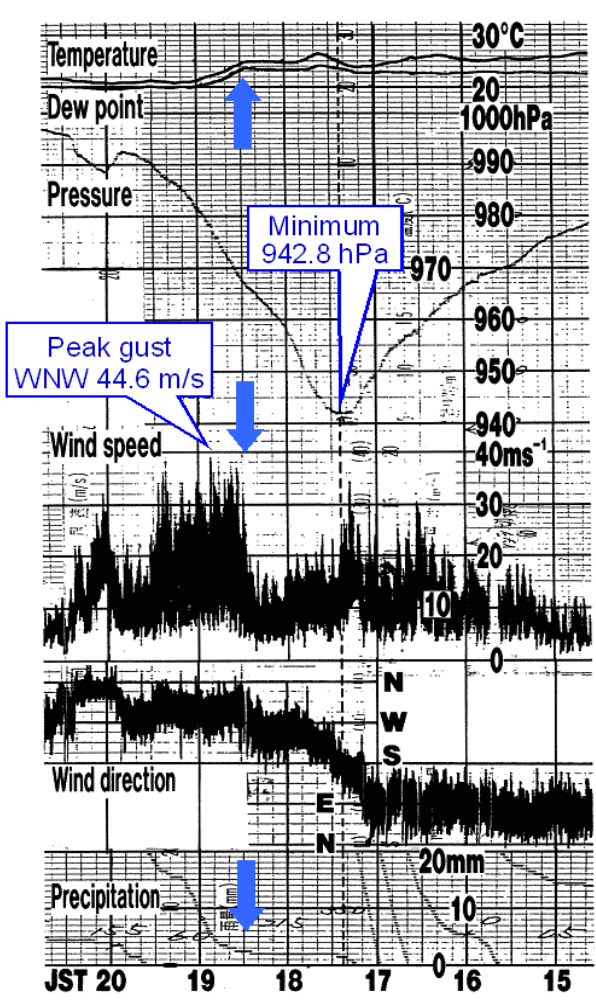

(b) T9119 (15-20 JST 27 Sep. 1991)

Fig. 10. Time series data at Fukuoka. Precipitation is presented in ten-minute values for T0418 and cumulative values for T9119. 


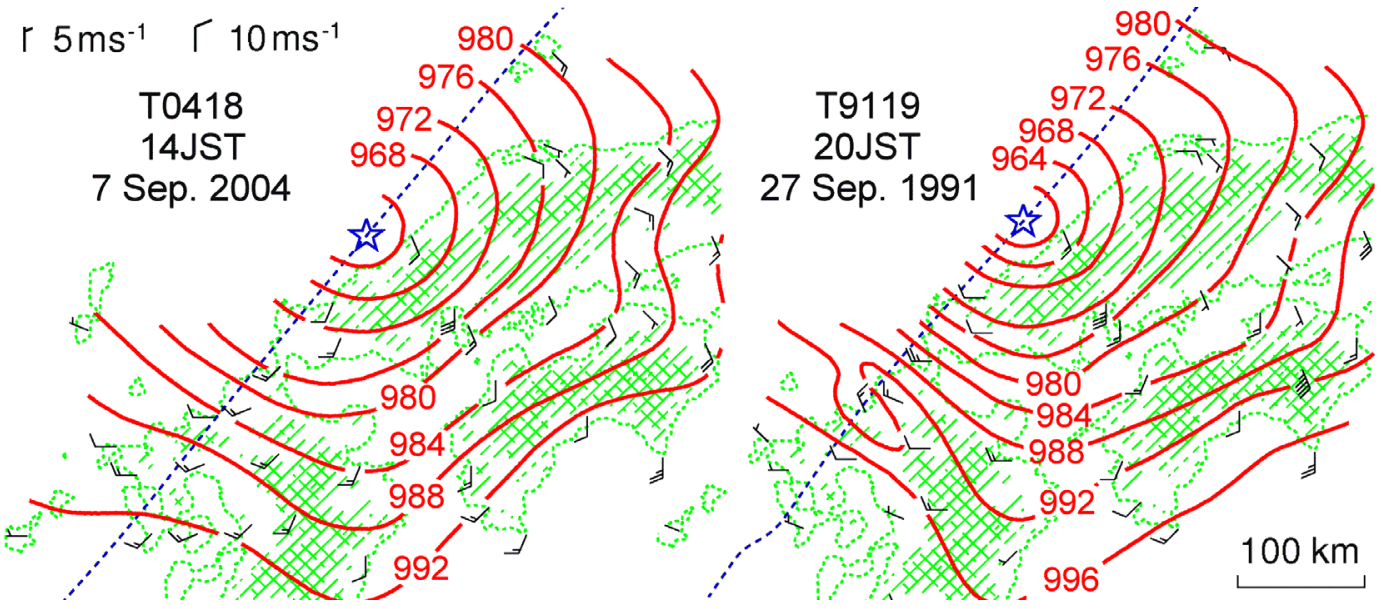

Fig. 11 Sea-level pressure fields and surface winds at each time displayed.

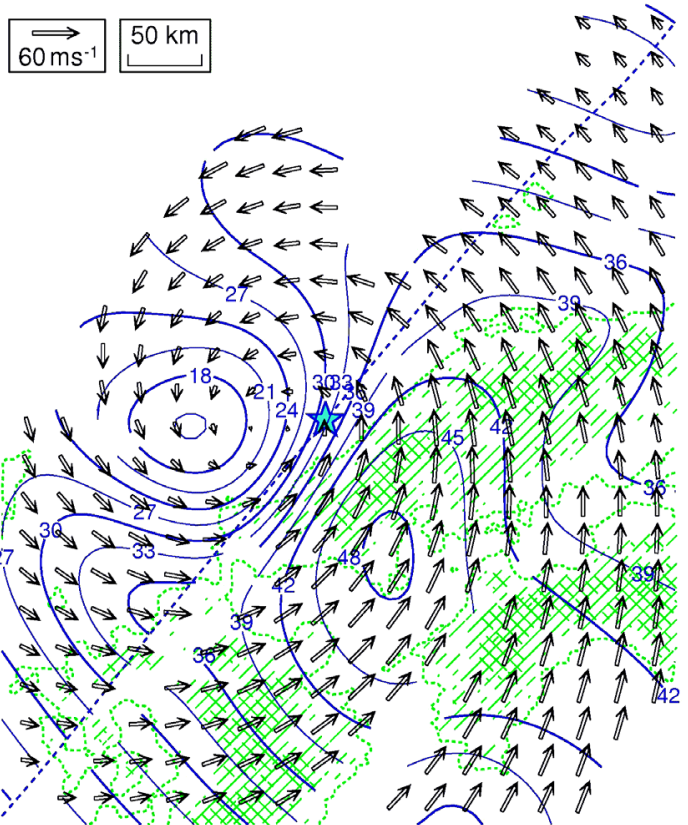

Fig. 12 Composite fields of wind vector (arrows) and wind speed (isotachs; $3 \mathrm{~ms}^{-1}$ intervals) at $1 \mathrm{~km}$ above the m.s.l. for six hours around the time displayed (see text for details).

strong northwesterly wind.

It is generally observed that winds around a moving typhoon are stronger on the right side than on the left side. Fujibe (1996) explained that the wind field near the center of a moving typhoon is given by the summation of the gradient wind for the stationary typhoon and the translation velocity, if friction is neglected. Figure 12 illustrates the composite fields of the horizontal wind vector and wind speed for T0418 at $1 \mathrm{~km}$ above m.s.l., where the effect of surface friction is expected to be negligible, which is obtained by superimposing ten-minute data of the wind-profiler network from $0900 \mathrm{JST}$ to $1500 \mathrm{JST}$ with respect to the storm position at $1400 \mathrm{JST}$. The central pressure was 945 to $950 \mathrm{hPa}$ during the six hours (Fig. 2).

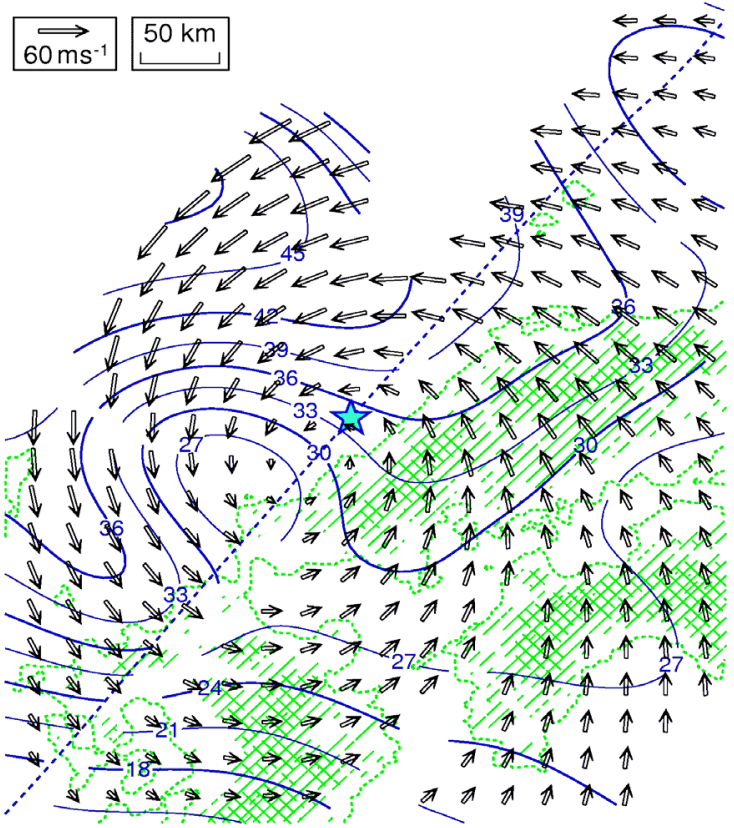

Fig. 13 Same as Fig. 12, but for the storm relative winds.

Analysis for the $1.5 \mathrm{~km}$ and $2 \mathrm{~km}$ levels (not shown) gives essentially the same result as presented here, indicating that the wind field at $1 \mathrm{~km}$ is almost free of surface friction. The main features of the wind field in Fig. 12 roughly agree with those at the surface (Fig. 9), with respect to maximum wind speed $\left(50 \mathrm{~ms}^{-1}\right)$ to the southeast of the center and minimum wind speed $\left(20 \mathrm{~ms}^{-1}\right)$ to the northwest. Figure 13 denotes the composite wind fields relative to the storm motion, which was northeastward (38.8deg) at an average speed of $64 \mathrm{~km} / \mathrm{h}$ from 0900 to 1500 JST. The difference of wind speed between each side of the track almost vanishes, although the vortex core deviates behind the center. Thus, the wind difference across the track of T0418 can roughly be explained by the translation of an axially symmetric 


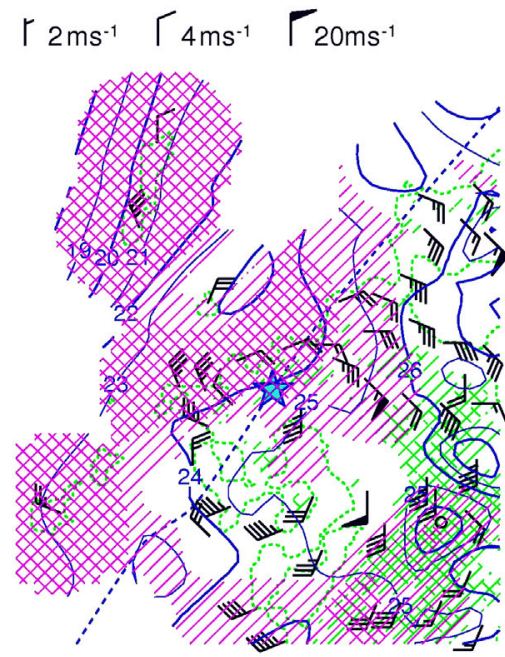

(a) 1700 JST, 27 Sep. 1991

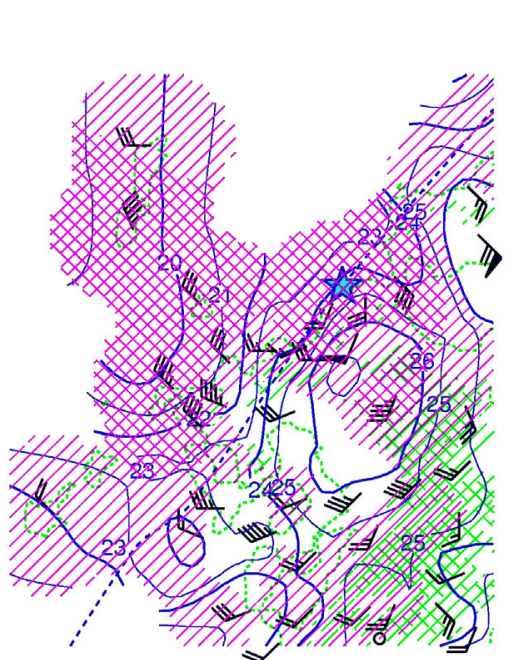

(b) 1800 JST, 27 Sep. 1991

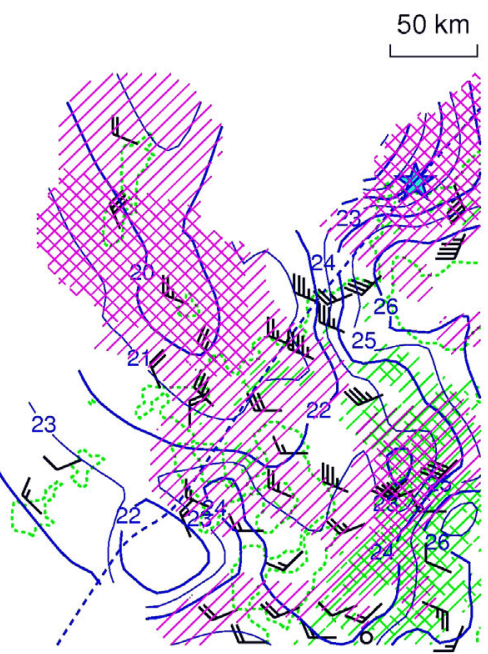

(c) 1900 JST, 27 Sep. 1991

Fig. 14 Surface wind, temperature, and rainfall in the preceding 60 minutes during the passage of T9119. Temperature and rainfall are displayed the same as in Fig. 9.

typhoon. This fact confirms that the strong northwest winds behind the center of T9119 should be regarded as a feature deviating from the symmetric wind field.

Figure 14 indicates the surface fields at 1700, 1800, and 1900 JST for T9119. The cold region with strong northwest wind was not present at $1700 \mathrm{JST}$, but rapidly developed in the left-rear quadrant by 1900 JST. In other words, the cold-surge-like feature was established within a few hours of landfall. In view of the intrusion of dry air to the west of the storm (Fig. 5), it is possible that dry air entrained in the rain-band behind the center caused evaporative cooling and generated the cold-air surge. Sakakibara et al. (2000) invoked a similar mechanism in the rear of T9807 (Vicki; 22 September 1998), which caused severe wind damage in the Kinki district (Okuda et al., 2003). This process did not work in T0418 because convective clouds behind the center almost disappeared after landfall.

\section{Summary and Remarks}

T0418 and T9119 made landfall on Kyushu and moved northeastward on nearly the same track, with severe winds in the southeastern semicircle. However, T9119 was accompanied by another area of strong winds in the left-rear quadrant associated with cold air under an intense rain-band, while the wind on the left side of T0418 was relatively weak. It is likely that dry air entrained in the rain-band generated a mesoscale cold-air surge and intensified the northwest winds in the left-rear quadrant of T9119. The T0418 wind field can roughly be explained by the storm motion superimposed on an axisymmetric typhoon.

After passing Kyushu, the two typhoons moved northeastward in the Sea of Japan and hit northern Japan (Fig. 1), which rarely experiences severe winds due to TCs. Although they were in the final stage of extratropical transition, they still had an intensity of 960 to $970 \mathrm{hPa}$ and peak gusts exceeding $50 \mathrm{~ms}^{-1}$. T9119 had a broad central area of nearly uniform pressure as it passed Hokkaido, with a steep pressure gradient and strong southwest winds on its southeastern side, while T0418 had a sharp pressure center with an area of strong wind near the center (Fujibe, 1993; Fujibe et al., 2005). A detailed analysis of the extratropical transition process of T0418 is under way, including the analysis of surface wind fields over the sea (Kitabatake, 2005).

\section{Acknowledgments}

The authors are grateful to Dr. Hitoshi Sakakibara, Meteorological College, for encouragement in this study. The Office of Statistics, the Observations Department of the JMA, provided part of the data used for analysis.

\section{References}

Akima, H., 1970: A new method of interpolation and smooth curve fitting based on local procedures. J. Assoc. Comput. Mach., 17, 589-602.

Fudeyasu, H. and T. Hayashi, 2001: General characteristics of pressure dip occurred within typhoon. Ann. Disas. Prev. Res. Inst., Kyoto Univ., No.44B-1, 159-169 (in Japanese with English abstract).

Fudeyasu, H. and T. Hayashi, 2003: A generation mechanism of meso- $\beta$-scale pressure dip in the tropical cyclone. Ann. Disas. Prev. Res. Inst., Kyoto Univ., No.46B, 651-661 (in Japanese with English abstract).

Fujibe, F., 1993: Features of strong winds associated with Typhoon 9119 compared with the cases of Typhoons 5415 and 6118. Tenki, 40, 403-412 (in Japanese).

Fujibe, F., 1996: On the formulae of wind distribution for a translating typhoon. Tenki, 43, 671-680 (in Japanese).

Fujibe, F. and T. Fujitani, 1993: Features of surface winds 
associated with Typhoon 9119 (Mireille). Agenda of the UJNR 25th Joint Panel Meeting (Tsukuba, 17-20 May 1993), 43-50.

Fujibe, F., N. Kitabatake, K. Bessho and S. Hoshino, 2005: Features of the wind fields associated with Typhoon 0418 (Songda) compared with those of Typhoon 9119 (Mireille). Agenda of the UJNR 37th Joint Panel Meeting (Tsukuba, 16-20 May 2005). (Available from http://www. pwri.go.jp/eng/ujnr/joint/37/paper/43fujibe.pdf )

Fujibe, F., A. Tabata and K. Akaeda, 1995: Features of surface wind fields in the south Kanto plain during the passage of a tropical storm and a mesoscale cold front. Tenki, 42, 617-626 (in Japanese).

Fujii T., T. Hayashi and Y. Mitsuta, 1992: On an analysis and a wind distribution of Typhoon 9119 (Mireille). Ann. Disas. Prev. Res. Inst., Kyoto Univ., No.35B-1, 183-191 (in Japanese with English abstract).

Kitabatake, N., 2005: Structure and intensity of typhoon Songda (2004) undergoing extratropical transition. WMO Tropical Meteorology Research Programme (TMRP) Commission for Atmospheric Sciences (CAS). Report of the International Workshop on Tropical Cyclone Landfall Processes. Macao, China, 21-25 March 2005.

Maeda, H., 1994: On the pressure dip within T9119. J. Meteorol. Res. JMA, 46, 25-38 (in Japanese).

Matsumoto, S. and Okamura, H. 1985: The internal gravity wave observed in the Typhoon T8124 (Gay). J. Meteorol. Soc. Jpn., 63, 37-51.
Nakamura, M., M. Joko, O. Tsukamoto, T. Kanamori, K. Azuma, K. Kawata, H. Kimura, N. Kamei, T. Kamata and H. Fudeyasu, 2002: Experimental study of the downslope wind ("Hiroto-kaze") occurrence at Mt. Nagi. Tenki, 49, 129-139.

Okuda, Y., H. Ishikawa and T. Fujii, 2003: An analysis on typhoon Vicki of 1998 based on surface meteorological records at fire stations. Natl. Disaster Sci., 25, 47-56.

Saito K., 1994: A numerical study of the local downslope wind "Yamaji-kaze" in Japan. Part 3: Numerical simulation of the 27 September 1991 windstorm with a non-hydrostatic multi-nested model. J. Meteorol. Soc. Jpn., 72, 301-329.

Sakakibara, H., F. Fujibe, N. Kitabatake, Y. Tanaka and K. Bessho, 2000: Mesoscale features of diverging strong winds associated with a typhoon in extratropical transition Preprints of 24th Conference on Hurricanes and Tropical Meteorology, 314-315.

Sakakibara, H., M. Ishihara and Z. Yanagisawa, 1985: Structure of a typhoon rainstorm in the middle latitudes observed by Doppler radar. J. Meteorol. Soc. Jpn., 63, 901-922.

Smith, R. B., 1982: Synoptic observations and theory of orographically disturbed wind and pressure. J. Atm. Sci., 39, 60-70.

Yamamoto R., Y. Mitsuta and K. Miyata, 1963: Some studies on Typhoon Nancy (6118). Ann. Disas. Prev. Res. Inst., Kyoto Univ., No.6, 113-127 (in Japanese) .

\title{
台風 0418 と台風 9119 による西日本の地上風分布の比較
}

\author{
藤部文昭（気象研究所予報研究部） \\ 北畠尚子・別所康太郎 - 星野俊介（気象研究所台風研究部）
}

\begin{abstract}
台風 $0418 （ 2004$ 年 9 月 7 8 日）と台風 9119 （1991 年 9月 27〜28 日）は互いによく似た経路で西日本を通り、ともに大き

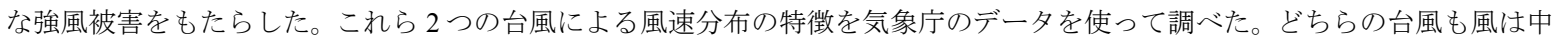
心の右側（南東側）で最も強かったが、台風 9119 は中心の左後方（西側）にも強風域を伴っていた。この強風域は強雨と低 温を伴っており、中心後方の降雨帯に乾燥空気が侵入することによる蒸発冷却によって形成されたと考えられる。これに対し て台風 0418 は中心後方の降雨が弱く、風速分布は軸対称な渦と移動速度との重なったものにほぼ近かったことが示された。
\end{abstract}

